людини. 3'ясування цього факту дозволяє зробити такі узагальнення: 3 одного боку, неможливість вербалізації емоційного переживання пояснює слабку вивченість питання методами описового хороведения; $з$ іншого - загальновизнана для хорового мистецтва значимість емоцій сприяє більш глибокому вивченню об'єктивних механізмів, що забезпечують виразне звучання хору, забезпечуючи розвиток апарату мислення самого хороведення. Звучання хорового твору створюється й забезпечується механізмами установчої діяльності. Розучуючи твір, працюючи над строєм, ансамблем, звуковидобуванням, артикуляцією тощо, диригент хору формує у своїх співаків комплекс вокально-хорової установки, який на виступі й буде керувати звучанням хору.

Вивчення закономірностей створення, фіксації та реалізації установчої діяльності багато в чому розширює можливості аналізу процесів хорової творчості.

\title{
Література
}

1. Доронюк В. Методика викладання диригування. - Івано-Франківськ, 2005.C. 32-42. 2. Дистервег А. Руководство к образованию немецких учителей /Адольф Дистервег: Избр. пед. соч. - М. : Учпедгиз, 1956. - 374 с. З. Коменский Я. А. Сочинения: пер. с чешск. и лат./ Ян Амос Коменский. - М. : Наука, 1997.476 с. 4. Рудницька О. П. Формування музичного сприйняття в системі розвитку педагогічної культури майбутнього вчителя: автореф. дис. на здобуття наук. ступеня док. пед. наук: 13.00.01 «Теорія та історія педагогіки» / О. П. Рудницька. - К., 1994. 42 с. 5. Узнадзе Д. Н. Психология установки /Дмитрий Николаевич Узнадзе. - СПб. : Питер, 2001. - 416 с. 6. Холопова В. Н. Музыка как вид искусства: [учебное пособие]/ Валентина Николаевна Холопова. - СПб. : Лань, 2000. - 320 с.

Василь Химинець

\section{НАУКОВО-МЕТОДИЧНІ АСПЕКТИ СТВОРЕННЯ ІННОВАЦЙНОГО СЕРЕДОВИЩА В РЕГІОНІ}

Химинець В. В. Науково-методичні аспекти створення інноваційного середовища в регіоні.

У статті розглядається вплив інформаційного суспільства на формування інформаційної культури вчителя. Проаналізовані структура та рівень сформованості інформаційної культури педагога, обумовлена необхідність використання інформаційно-комунікаційних технологій на уроках, що забезпечують ефективність навчального процесу.

Ключові слова: суспільство, освіта, науково-методична робота, інноваційне середовище, інформація, інформатизація, інформаційна культура педагога, інформаційно-комунікаційні технології.

Химинец В. В. Научно-методические аспекты создания инновационной среды в регионе.

В статье рассматривается влияние информационного общества на формирование информационной культуры учителя. Проанализированы структура и уровень сформированности информационной культуры педагога, обусловлена необходимость использования информационно-коммуникационных технологий на уроках, обеспечивающих эффективность учебного процесса.

Ключевые слова: общество, образование, научно-методическая работа, инновационная среда, информация, информатизация, информационная культура педагога, информационно-коммуникационные технологии. 
Hymynets V. V. Scientific and methodological aspects of the innovative environment in the region.

The article examines the impact of the information society in the formation of information culture teacher. The structure and level of formation of information culture of the teacher due to the necessity of using information technologies in the classroom kompunikatsiynyh to ensure the effectiveness of the learning process.

Keywords: society, education, scientific and methodical work, innovative environment, information, information, information culture teachers, information and communication technologies.

Одним із важливих завдань для сучасної педагогічної науки і практики є пошук ефективної системи освіти, яка відповідала б потребам соціально-економічного і культурного розвитку суспільства, сприяла вчителеві у його прагненні творчо й ефективно працювати та допомагала учневі самовизначитися і самореалізуватися в соціально-культурному середовищі.

Успіх становлення і розвитку сучасного освітнього закладу значною мірою визначається знаннями, творчим потенціалом, професійною майстерністю і загальною педагогічною культурою його працівників. У сучасних умовах значення творчості в роботі вчителя незмірно підвищується, адже саме від творчого підходу до розв'язання тих складних і багатогранних завдань, які стоять нині перед навчальними закладами, значною мірою залежать ефективність педагогічної праці, якість навчально-виховного процесу, розвиток творчих здібностей вихованців.

Mema cmammi: показати, що науково-методична робота в школі $є$ найбільш ефективною за умови створення інноваційного середовища в регіоні.

Удосконалення навчально-виховного процесу в школі нині здійснюється в контексті таких глобальних освітніх тенденцій [3]:

- масовий характер освіти та її неперервність;

- адаптація освітнього процесу до запитів і потреб особистості;

- орієнтація навчання на інновації, особистість, забезпечення можливостей іiі саморозвитку та саморозкриття, загальні та фахові компетенції;

- людиноцентристське спрямування освіти та гуманістична спрямованість інноваційних процесів;

- організаційні, структурні та змістові нововведення в навчально-виховний процес, підпорядковані принципу «освіта впродовж всього життя».

За таких умов зростають вимоги не тільки до якості сучасної освіти, але й до науково-методичної підготовки вчителя. Аналіз навчально-виховної діяльності й якісного складу педагогічних кадрів сучасних освітніх закладів та об'єктивна потреба в застосуванні наукових знань, досягнень науково-технічного прогресу у практичній діяльності зумовлюють особливу актуальність проблеми ефективної організації науково-методичної роботи з учителями.

Науково-методична робота в навчальних закладах розглядається [2; 5] як цілісна система підвищення науково-теоретичного і загальнокультурного рівня, психологопедагогічної підготовки й професійної майстерності педагогів, формування в них готовності до самоосвіти, саморозвитку. Система науково-методичної роботи покликана задовольняти потреби розвитку й оновлення школи, інтереси педагогічних колективів та окремих учителів у постійному підвищенні фахового рівня відповідно до кон'юнктури ринку педагогічної праці, бути засобом соціального захисту освіти й освітян. Правильно побудована науково-методична робота сприяє також формуванню позитивного 
психологічного клімату в педагогічному колективі, постає ефективним мотивуючим чинником до навчально-виховного процесу [4].

До основних функцій науково-методичної роботи нині прийнято відносити: організаційну, діагностичну, прогностичну, відновлювальну, корегуючу, координуючу, контрольно-інформаційну [4]. Особливості методичної роботи в школах нового типу зумовлені метою та системою організації навчального процесу в них. У навчальновиховних закладах склалася певна система науково-методичної роботи з педагогами, яка передбачає індивідуальні, групові та масові форми, що перебувають в органічній єдності, взаємодіють і доповнюють одна одну. Форми організації такої роботи досить різноманітні, але одне 3 домінуючих місць посідає науково-методична робота, що проводиться безпосередньо в освітньому закладі.

Суттєвою особливістю $є$ те, що методична робота в сучасних освітніх закладах має суто науковий характер. Новий зміст освіти, освоєння нових навчальних програм, створення авторських програм, викладання нетрадиційних дисциплін, пошук оригінальних методик викладання - усе це спонукало вчителя до творчої дослідницької роботи. Науково-пошукова діяльність педагогів, як свідчить практика, спрямована головним чином на: розроблення структури шкільного компонента навчального плану; визначення змісту навчальних предметів для профільних класів, курсів за вибором із врахуванням інтересів учнів і батьків, матеріально-технічних можливостей школи, забезпеченості викладацькими кадрами; створення навчальних програм, методичного і дидактичного забезпечення навчального процесу необхідним унаочненням; розроблення й апробування навчальних посібників і підручників для викладання предметів шкільного компонента; розроблення змістовно-методичного й організаційного аспектів диференціації та індивідуалізації навчання учнів.

У цьому контексті важливого значення для успішного функціонування системи науково-методичної роботи в освітньому закладі набуває координація такої діяльності 3 інститугами післядипломної педагогічної освіти, педагогічними ВНЗ, регіональними науково-методичними центрами, районними методичними кабінетами, районними та шкільними методичними об'єднаннями та окремими носіями передового педагогічного досвіду. Окрім цього, координуюча функція науково-методичної роботи в освітньому закладі покликана усунути дублювання в діяльності, вона передбачає раціональне поєднання інформаційної поінформованості всіх освітніх структур у певному проміжку часу. Організачійна функиія нерозривно пов'язана 3 коригуючою та діагностичною, оскільки аналіз, відновлення й корекція знань, умінь i навичок- зближені поняття та взаємодоповнюють одне одного з огляду на послідовність і неперервність процесу навчання.

Особливе місце в системі методичної роботи в освітніх закладах відводиться діагностувальній роботі з учнями, розробленню практичних рекомендацій 3 методики і змісту індивідуальної роботи 3 ними. Ось чому в структурі методичної роботи сучасної школи доцільно створити психолого-діагностичну службу, яка б забезпечувала діагностування учнів, вивчення їхніх психологічних особливостей і на цій основі - організацію роботи вчителів щодо індивідуалізації навчання, конкурсного відбору дітей у навчальний заклад.

Важливу роль у системі науково-методичної роботи відіграє і прогностична функція, яка дозволяє прогнозувати та передбачати результати освітньої діяльності, підвищує ступінь науковості нововведень та покликана запобігати допущенню різного роду педагогічних помилок. Моделююча функція дозволяє учасникам педагогічного експерименту змоделювати, а отже й передбачити всі його етапи та можливі результати в теоретичній площині. Вона сприяє процесу формування та впровадженню в 
навчально-виховний процес нових педагогічних технологій та моделей передового педагогічного досвіду.

Відновлювальна функція системи науково-методичної роботи спрямована на відновлення знань і вмінь, які частково забуваються чи втрачаються педагогами з часом або у зв’ язку зі зміною діяльності. Основне призначення коригувальної функції полягає у вчасному усуненні недоліків та внесенні відповідних випралень і доповнень у педагогічний процес, який уже здійснюється. Координуюча і контрольно-інформаційна функції спрямовані на подолання можливого дублювання та реалізації зворотного зв’ язку на всіх етапах науково-методичної діяльності освітнього закладу.

Науково-методична робота в школі розв’язує, як правило, такі основні завдання: інноваційний розвиток школи - створення інноваційного середовища; формування фахового, насамперед науково-методичного, потенціалу педагогічного колективу; розвиток індивідуальної педагогічної діяльності педагога; формує систему роботи 3 обдарованими учнями.

Організатором методичної роботи в освітніх закладах $\epsilon$ заступник директора 3 науково-методичної роботи. Він аналізує педагогічну діяльність учителів, визначає їх потребу в підвищення професійної кваліфікації і педагогічної майстерності; планує внутрішньошкільну науково-методичну роботу та контролює іï виконання; організовує і проводить семінари, лекції, конференції, педради, педчитання та інші внутрішньошкільні заходи щодо підвищення рівня кваліфікації педагогічних кадрів; координує роботу закладу з науково-дослідними та педагогічними інститутами, інститутами вдосконалення вчителів, іншими освітніми закладами та відділом освіти району (міста); надає допомогу керівникові освітнього закладу у проведенні атестації педагогічних кадрів; укладає угоди про співдружність та спільну діяльність науковців і педагогічного колективу з питань навчальної та науково-методичної роботи; підтримує зв'язки 3 іншими освітніми закладами 3 обміну документацією, методичними розробками, делегаціями вчителів та учнів, 3 проведення спільних заходів науково-методичного чи навчально-виховного характеру; вивчає та узагальнює кращий досвід учителів, сприяє його впровадженню; здійснює організацію науково-дослідної роботи вчителів та учнів.

На сучасному етапі розвитку загальноосвітньої школи внутрішньошкільну науково-методичну роботу доцільно вести за такими основними напрямами: удосконалення змісту науково-методичної роботи, забезпечення іï національної спрямованості відповідно до економічних, політичних, соціально-культурних умов розбудови й оновлення української загальноосвітньої школи; поглиблення філософськопедагогічних знань, що спрямовані на відродження та розвиток національної освіти в Україні, вивчення педагогами теорії і методики навчання та виховання, основ психології, етики, естетики, поглиблення науково-теоретичної підготовки з предмета та методики його викладання з урахуванням вимог Закону про мови в Україні; вивчення діалектики та принципів розбудови української національної школи; збагачення педагогічних кадрів надбаннями української етнопедагогіки, науки, культури; вивчення питань теорії і досягнень науки в галузі викладання предмета, володіння сучасною науковою методологією; глибоке вивчення та практична реалізація програм i підручників, розуміння їх особливостей і вимог з позиції формування національної школи; засвоєння методики викладання нового предмета; випереджувальний розгляд питань методики вивчення складних розділів навчальних програм 3 демонструванням відкритих (показових) уроків; удосконалення методики застосування наочних посібників, технічних засобів навчання, дидактичних матеріалів; засвоєння та практичне застосування теоретичних положень загальної дидактики, методів і прийомів активізації навчальної діяльності школярів і формування в них наукового світогляду, виходячи 3 
вимог етнопедагогіки; систематична інформація про нові методичні рекомендації, публікації щодо змісту та методики навчально-виховної роботи, глибоке вивчення відповідних державних і нормативних документів; упровадження у практику роботи педагогічних колективів досягнень етнопедагогіки, психології й окремих методик, передового педагогічного досвіду, передовсім зважаючи на впровадження в діяльність педагогічного колективу зразків національної культури і традицій [10].

Системність методичної роботи можна забезпечити тоді, коли іiі змістом буде вдосконалення шкільної навчально-виховної системи, компонентами якої є: мета, зміст, методи, засоби й організаційні форми навчання, виховання і розвитку учнів. Отже, методична робота має бути зорієнтованою на прогностичне обгрунтування відповідних компонентів навчально-виховної системи.

Методологічною основою змісту шкільної освіти мають стати загальнолюдські й національні цінності, зосередженість на актуальних і перспективних інтересах учня. Зміст сучасної освіти має грунтуватися на людиноцентристській парадигмі та закладати фундамент для побудови демократичного суспільства. У цьому контексті одним із важливих напрямів діяльності педагогічного колективу є визначення мети навчання та виховання учнів і втілення ії у своєрідній прогностичній моделі випускника певного навчального закладу.

Як правило, методична робота в школі зводиться до вивчення окремих методик. Комплексний підхід до змісту методичної діяльності вчителів передбачає обов'язковість тісного зв'язку методичної роботи 3 іншими видами підготовки вчителів, зокрема, психолого-педагогічної, етичної, дидактичної, загальнокультурної, технічної. Причому визначення змісту і форм методичної підготовки вчителів має вестися 3 урахуванням професійних інтересів та потреб кожного вчителя. Законом шкільного життя має стати щорічне проведення науково-практичних конференцій 3 актуальних питань навчальновиховного процесу. Науково-практична конференція як форма внутрішньошкільної науковометодичної роботи покликана підвести підсумки роботи колективу школи 3 певної педагогічної проблеми. Освітянська конференція постає формою узагальнення педагогічного досвіду вчителів різних фахів, осмислення досягнутого рівня, вона спрямовує колектив на розв'язання нових науково-методичних проблем. Науково-практична конференція також підвищує роль науки та відповідальність дидактів та вчителів-практиків за рівень проведених наукових досліджень та їх упровадження в педагогічну практику.

Загалом науково-методична робота в школі $\epsilon$ складником єдиної системи безперервної освіти педагогічних працівників і розуміється як цілісна, заснована на досягненнях науки, передового досвіду і конкретному аналізі професійних потреб учителів система взаємопов'язаних заходів, дій, засобів, спрямованих на підвищення професійної майстерності кожного педагога, збагачення і розвиток творчого потенціалу кожного педагогічного колективу, а в кінцевому результаті- на досягнення оптимальних результатів освіти, виховання і розвитку особистості.

Методологічне спрямування пошуково-дослідної діяльності пов'язане з самостійним розробленням закладом освіти нових педагогічних ідей, цілей, завдань, форм роботи, функцій, методів і принципів, закономірностей організації та проведення навчально-виховного процесу.

Розроблення концепцій розвитку школи, моделей закладів освіти нового типу, авторських програм, створення нових теоретичних положень і технологій зобов'язує дослідника до формування та розвитку в собі найважливіших для педагога особистісних якостей: уміння здійснювати такі складні розумові операції, як узагальнення, абстрагування, ідеалізація, моделювання, систематизація, інтеграція, прогнозування тощо. У педагога повинні бути розвинені рефлексія, інтуїція, передбачення, дослідницьке чуття. 
Алгоритм методологічного дослідження містить такі операції: здійснення рефлексії особистої практичної діяльності; виявлення суперечності між теорією та практикою; пошук теоретичних положень, які допомагають знайти засоби і шляхи розв'язання та зняття суперечності; встановлення відсутності в теорії, а іноді й у практиці, відповіді на питання, що було поставлене під час дослідження; гіпотетичне формування нової ідеї, яка пояснює суперечність або допомагає його зняти; аналіз і підбір фактів із педагогічної практики, які підкреслюють ефективність ідеї; складання графічної і вербальної моделі, іiї опис та оформлення висновків.

Інститути післядипломної педагогічної освіти як навчально-виховні і наукові ВН3 III-IV рівнів акредитації задля формування інноваційного середовища в регіонах, покликані виконувати такі основні взаємопов'язані між собою функції $[6 ; 9 ; 10]$ :

- удосконалювати фаховий рівень освітян;

- забезпечувати науково-методичне супроводження інновацій;

- здійснювати регіональні, фундаментальні та прикладні наукові психологопедагогічні дослідження;

- координувати наукові психолого-педагогічні дослідження в регіоні.

Науково-методичне супроводження полягає в тому, що це $є$ професійна взаємодія суб'єктів педагогічної діяльності щодо спільного опанування організаційних та навчально-виховних інновацій. Визначальними основами інноваційного науковометодичного супроводження навчально-виховного процесу в ІППО є [4; 8]:

- демократичність - можливість урахування різних підходів, точок зору, колегіальність у прийнятті певного рішення;

- ситуація вибору - створення кількох варіантів програм, моделей діяльності, технологій, які забезпечують передумови для свідомого вибору;

- самореалізація - розкриття особистісного потенціалу кожного учасника педагогічного процесу;

- співтворчість - спільна діяльність суб'єктів, які прагнуть досягти нових кількісних і якісних результатів;

- синергетичність - нелінійність, нестабільність як процесуальні характеристики та самоорганізація системи науково-методичного супроводження.

Формування особистості сучасного вчителя безпосередньо пов'язане 3 необхідністю модернізації внутрішньошкільної науково-методичної та науководослідної роботи, ії вдосконаленням на основі запровадження інноваційних технологій у навчально-виховний процес. Ідеться насамперед про залучення педагогів-практиків до творчої та дослідницько-експериментальної діяльності і формування в них нових підходів до організації науково-методичної роботи, нового розуміння педагогічної творчості. Дослідно-експериментальну діяльність шкільного педагога необхідно розглядати як форму педагогічної творчості - з одного боку, і як умову позитивного розвитку шкільної навчально-виховної системи - 3 іншого. У цьому ракурсі процес модернізації науково-дослідної роботи, який окреслився в роки оновлення освіти та розбудови української національної загальноосвітньої школи, має стійку позитивну тенденцію.

Пріоритетними завданнями науково-методичної роботи як структурної ланки післядипломної освіти педагогічних працівників $\epsilon$ [1; 4]:

- трансформація наукових ідей у педагогічну практику;

- упровадження сучасних особистісно зорієнтованих методів і форм організації освітнього процесу, інформаційних технологій; відновлення пріоритетів виховання;

- системний моніторинг змісту, форм i методів освіти, іiі якостей та результативності; 
- науково-методичне забезпечення розвитку освітніх установ і закладів;

- аналіз та розроблення сучасних концепцій, навчальних програм, посібників, підручників, сприяння створенню умов для реалізації варіативної частини навчальних планів, поглибленого вивчення предметів, профільного навчання з урахуванням потреб регіонів;

- вивчення, узагальнення, поширення перспективного педагогічного досвіду, методична інструментовка матеріалів виставок педагогічних ідей і знахідок;

- сприяння соціалізації педагогів і учнів в умовах інформаційного суспільства;

- створення оптимальної системи інформаційного забезпечення та інформаційноаналітичного обслуговування навчально-виховного процесу та управління ним.

Разом 3 міськими (районними) методичними службами інститути післядипломної педагогічної освіти керують експериментальною та науково-дослідною роботою вчителів, яка логічно охоплює:

- діагностично-прогностичну роботу - виявлення творчих учителів та скерування їх на створення інноваційного середовища в конкретному навчально-виховному закладі;

- підвищення загального і фахового рівня вчителів, які експериментують та запроваджують інновації;

- мотивацію дослідно-експериментальної діяльності та здійснення контролю за етапами ії виконання;

- науково-методичний та інформаційний супровід дослідно-експериментальної діяльності;

- запровадження розроблених методик, технологій і позитивного досвіду в інших освітніх установах регіону.

Досвід роботи показує, що залучення освітян до науково-дослідної діяльності є ефективним за використання певних алгоритмів, насамперед:

- розвинені інтелектуальні якості: загальний інтелект, творче та критичне мислення (здатність оцінювати ідеї, контролювати інформацію, переробляти, адаптувати або відкидати іiі);

- інноваційний потенціал: усвідомлена потреба в НДД, здатність до проективної діяльності: здатність генерувати нові ідеї, відкритість особистості до нового, до альтернативних думок;

- знання і навички навчально-пошукової і дослідницької діяльності: володіння методикою педагогічних досліджень, навичками аналізу результатів дослідження, аналізу стану викладання предмета; вміння працювати з літературою та Інтернетом, створення програм власної навчально-дослідницької діяльності;

- здатність до проективної діяльності: прогнозування результатів НДР, створення програми дослідження, iі апробація та впровадження; психолого-педагогічне проектування особистісної розвивальної взаємодії суб'єктів навчально-виховного процесу;

- створення соціальних, психолого-педагогічних умов для інноваційної освітньої діяльності: діагностика готовності педагогів до ІОД (мотиваційної, психологічної, інформаційної, технологічної); наявність матеріально-технічного забезпечення;

- створення організаційно-педагогічних умов для діяльності вчителів-дослідників: заходи 3 підвищення кваліфікації за проблемами дослідження, створення шкіллабораторій, майстер-класів, творчих груп тощо; методичний супровід пошукової діяльності, координація роботи творчих колективів;

- розвиток новаторських процесів: наукова експертиза результатів дослідження, презентація напрацювань (творчі портрети, відкриті уроки, виставки тощо), створення 
електронного банку педагогічних інновацій, кращого педагогічного досвіду, стимулювання учасників процесу.

Власне кажучи, уся науково-методична діяльність сучасного педагогічного колективу скеровується на створення інноваційного середовища, яке передбачає: загальне розуміння необхідності введення інновації в навчально-виховний процес (від директора школи до учня); відповідний фаховий рівень учителів закладу; створення відповідної матеріально-технічної бази; залучення науковців - працівників ВНЗ, інститутів ППО.

Важливо, щоб вибір інновації, яка впроваджується, був науково обгрунтованим для типу навчального закладу. Вибір має спиратися на: мету, яку ставить перед собою навчально-виховний заклад; фаховий рівень учителів, які будуть запроваджувати цю інновацію; юридичне забезпечення інноваційного процесу.

Варто усвідомити, що інновація не може бути ідеєю на показ, черговим педагогічним прожектом. Ефект можуть створити і прості педагогічні рішення або навіть і навчальні трюки. Ефективності досягають тільки через комплексну, планомірну роботу, яка спирається на психолого-педагогічну науку. Педагогічні інновації- це результат творчого пошуку оригінальних, нестандартних рішень різноманітних педагогічних проблем [7; 8].

Прямим продуктом інновацій є: нові навчальні технології, оригінальні виховні ідеї, форми та методи виховання, нестандартні підходи в управлінні. Побічним продуктом інновацій $\epsilon$ : зростання педагогічної майстерності вчителя i керівника, рівня його культури, мислення, світогляду. Інноваційна освітня діяльність передбачає: залучення освітян до творчої діяльності; створення ними нових чи вдосконалення наявних педагогічних продуктів (процесів, явищ).

Інтегративними ознаками інноваційної навчально-виховної системи $є$ : наявність загальної мети i призначення, які задаються і неперервно корегуються суспільством; ефективна система управління - цілеспрямованість організаційних та функціональних векторів іï діяльності; взаємозалежність структурних елементів в горизонтальному i вертикальному напрямках; відкритість усіх складників освітньої системи для впливу з боку соціуму і здатність до кореляційного розвитку разом з ним; неперервний вплив зовнішніх глобалізаційних і внугрішніх факторів на розвиток та існування системи і їі підсистем.

Під час вибору варіанта системи науково-методичної роботи враховуються конкретні умови і передовсім освітні та виховні завдання навчального закладу, кількісний і якісний склад педагогічного колективу, фінансові, матеріальні та моральнопсихологічні умови, створені в колективі.

Отже, необхідність підвищення ефективності i якості навчально-виховного процесу в школі потребує, щоб методична робота вчителів носила прогностичний, системний, комплексний, диференційований характер, тобто набула ознак науководослідницької інноваційної діяльності.

\section{Література}

1. Гуменюк В. В. Науково-методична робота з педагогічними кадрами: [наук-мет. Посібник] / В. В/ Гуменюк, І. А Наумчук. - Хмельницький: ПП Мошак, 2005. - 160 с. 2. Жерносек І. П. Науково-методична робота в загальноосвітні школі: [навч. метод. посібник] / І. П. Жерносек. - К. : ІЗМН, 1998. - 160 с. 3. Національна доктрина розвитку освіти України в XXI столітті. - К., 2001. - 24 с. 4. Організаційно-педагогічні основи методичної роботи: [навч.-мет. посібник] / за ред. В. І. Пуцова. - К., 1995. - 180 с. 5. Сгадова В. В. Методичній роботі - науковий характер: зб. наук. праць / В. В. Сгадова // Педагогічні інновації у сучасній школі. - К., 1994. - С. 49-53. 6. Химинець В. В. Взаємозв'язок науково-дослідної роботи Закарпатського ІППО 3 
розвитком шкіл області: [текст] / В. В. Химинець // Освіта Закарпаття. - 2006. - №3. С. 3-11. 7. Химинець В. В. Інноваційна освітня діяльність: [монографія] / В. В. Химинець.Тернопіль : Мандрівець, 2009. - 360 с. 8. Химинець В. В. Інноваційно-гуманістичне спрямування сучасної освіти / В. В. Химинець // Педагогіка і психологія. - 2010.№3(68). - С. 15-24. 9. Химинець В. В. Науково-методичні аспекти підвищення фахової майстерності вчителів / В. В. Химинець // Вісник післядипломної освіти. - 2005. - В.1. С. 78-88. 10. Химинець В. В. Науково-методичні аспекти розвитку післядипломної педагогічної освіти на зламі століть: [текст]/ В. В. Химинець // Освіта Закарпаття. 2005. - № 1. - C. 8-14.

\section{Микола Юдін}

\section{ТЕАТР ЯК ОДИН ІЗ НАЙВПЛИВОВІШИХ ЗАСОБІВ ЕСТЕТИЧНОГО ВИХОВАННЯ}

Юдін М. М. Театр як один із найвпливовіших засобів естетичного виховання.

У статті розглядаються проблеми естетичного виховання дітей i молоді на сучасному етапі розбудови українського суспільства та висвітлюється перспективна роль театру в цьому процесі.

Ключові слова: естетичне виховання, театр, культура, духовність, мистецтво, діти, молодь.

Юдин Н. М. Театр как одно из наиболее влиятельных средств эстетического воспитания.

В статье рассматриваются проблемы эстетического воспитания детей и молодежи на современном этапе развития украинского общества и освещается перспективная роль театра в этом процессе.

Ключевые слова: эстетическое воспитание, театр, культура, духовность, искусство, дети, молодежь.

Yudin N. M.Teatr as one of the most influential means of aesthetic education.

In the article it is shown the problems of esthetic upbringing of children and youth on the modern stage of building Ukrainian society. Also it is shown the perspectives of the role of the theatre in this process.

Key words: esthetic upbringing, theatre, culture, spirituality, art, children, youth.

В умовах інтенсивної глобалізації суспільства, де пріоритетним стає техногенний напрямок його розвитку, поступово втрачає свою вагомість естетичний, чуттєвий складник життєдіяльності людства.

Особливо небезпечним, на нашу думку, $\epsilon$ те, що ці процеси позначаються на вихованні дітей і молоді. Тож людство, якщо не змінити ситуації, може втратити в собі найцінніше - здатність до естетичного, чуттєвого сприйняття світу.

Актуальність проблеми полягає в тому, що духовні підвалини держави завтрашньої закладаються і формуються в душах дітей сьогоднішніх. Ось чому так важливо невідкладно акцентувати увагу всієї педагогічної спільноти на необхідності активізації естетичного виховання. При цьому варто наголосити, що Україна має достатній арсенал засобів естетичного виховання, але одним із найефективніших об'єктивно має стати театр як наймогутніший синтетичний вид професійного мистецтва. 